\title{
COMMUNICATION TECHNIQUES FOR GIFTED/TALENTED SUPPORT TEACHERS
}

\author{
BETH K. BERGHOFF, PH.D. \\ School Psychologist \\ Cumberland Co. (N. C.) Schools \\ PAUL J. BERGHOFF, PH.D. \\ Associate Professor of Education and Special Education \\ Pembroke State University \\ Pembroke, N.C.
}

The role of support teachers can be challenging, but it can also be frustrating. Many potential consultees* are threatened by having someone tell them how to try another way of working with the children they teach. Before support teachers can be effective, their potential clients must trust them as people and value their services. Being successful support teachers requires more than suggesting new ideas and materials for enriching the curriculum, it requires skillful communication techniques to ensure that the consultees are likely to accept these ideas and act on them.

The goal of support teachers is to help classroom teachers enrich and diversify the curriculum in order to meet the needs of gifted/talented students. Support teachers can offer (1) strategies for teaching gifted/talented students, (2) supplementary materials for use in teaching gifted/talented students, (3) assistance in developing and implementing individual educational programs, (4) assistance in utilizing community resources, (5) direct resource instruction with the identified students, and (6) staff development. Support teachers need to facilitate communication and help the regular classroom teachers individualize and meet students' needs. It is unrealistic to expect classroom teachers to meet the needs of gifted/talented students without assistance and support. In assisting classroom teachers, support teachers need to be certain that they enhance, not reduce, the classroom teachers' feelings of self-esteem, adequacy, and competence.

Support teachers do not want classroom teachers to feel angry, resentful, guilty, or defensive. They want them to feel supported, capable, and resourceful. The following guideline is suggested for the support teachers' role:

1. Inform classroom teachers of your services and express your

* Consultee refers to anyone who receives assistance from a consultant or resource teacher. 
willingness to help. Offer your services to meet the program's needs. Be specific-list the types of things that you can do, i.e., design learning centers, gather materials for independent student projects, work with small student groups, etc.

2. If a teacher seems receptive, ask if you might be able to "get together" so you can learn more about the program. Perhaps a classroom visit and/or demonstration could be arranged.

3 . If a teacher would like to meet with you, offer a choice of times for the meeting.

4. Do your best to pick a comfortable setting, emotionally and physically. It may be difficult to talk in the back of the classroom or in the lounge with other teachers listening.

5. Keep your meeting to a reasonable amount of time. A half hour to an hour should be sufficient for an initial meeting.

6. Express your appreciation to the teacher for taking time to meet with you. Briefly state the reason for the meeting, e.g., "I appreciate your meeting with me today to help me learn more about your classroom settings and to let me share some of my ideas and materials with you."

7. Convey feelings of respect for the teacher's job and the importance of the teacher's role with the child. Respect is communicated by (1) listening to both the feelings and content of the teacher's communication and (2) demonstrating that you are listening by restating the teacher's message in your own words. For example, "It's really frustrating to do all that work, preparing for your students and then learn that you must do even more preparation to meet the needs of your identified gifted/talented students." Gazda, Asbury, Balzer, Childers, \& Walters in Human relations development: A manual for educators, (1977) present systematic training in listening skills.

8. Be encouraging and supportive. In their book, Encouraging children to learn, Rudolph Dreikurs and Don Dinkmeyer suggest guidelines for being encouraging. Some possible encouraging statements that support teachers might make are:
A. "You do a good job of individualizing in your classroom."
B. "You have really changed the way you are. ..."
C. "You can help your students by. ..."
D. "So you made a mistake. What can we do now so it won't happen again?"
E. "Keep trying. Don't give up. All of us have some rough starts."


9. In working on a specific lesson or subject area try to see it from the classroom teacher's point of view. Hear the teacher's concerns and frustrations.

10. Be realistic. Consider the limitations of the environment, the teacher, and the student.

11. Formulate a complete program with the teacher for working with gifted/talented students in the classroom. Be specific. Be sure the teacher understands and accepts the proposed program. Be sure the teacher is willing and able to carry out the program.

12. Provide the teacher with materials needed for implementing the program.

13. Offer to loan the teacher any material to which you have access.

14. Be sure to tell the teacher that any of the ideas and/or materials that you supply can be used with any student, not just those identified as gifted/talented.

15. Offer follow-up support. Let the teacher know how to reach you and when you will be by again.

Support teachers need to modify the above steps to fit their personalities and situations. Be aware that classroom teachers often want to do what is best for students but need encouragement and support in order to carry out what needs to be done. Anything support teachers can do to make classroom teachers' jobs more rewarding will benefit gifted/talented students.

\section{REFERENCES}

Dinkmeyer, D. \& Dreikurs, R. Encouraging children to learn. Englewood Cliffs, N. J.: Prentice-Hall, 1963.

Gazda, G. M., Asbury, F. R., Balzer, F. J., Childers, W. C., Walters, R. P. Human relations development: a manual for educators. Boston: Allyn and Bacon, 1977 (2nd ed.). 